\title{
ANALISIS TERHADAP PELAKSANAAN AQAD PEMBIAYAAN DENGAN PRINSIP MUDHARABAH PADA BANK SYARIAH DALAM KAJIAN UU NO. 21 TAHUN 2008 TENTANG PERBANKAN SYARIAH
}

\author{
Oleh
}

Prof. H. Abdullah Kelib, SH dan Sodikul Amin

\begin{abstract}
ABSTRAK
Perjanjian Pembiayaan Mudharabah didasarkan kepada kepercayaan, dengan pengertian lain bahwa pemodal akan menyerahkan dananya kepada pihak pengelola dana setelah pemodal merasa yakin bahwa peminjam modal tersebut baik secara skill maupun moral dapat dipercaya untuk mengelola modal yang diberikan dengan keahliannya dan tidak akan memanipulasi modal tersebut. Namun bukan berarti dalam pelaksanaan perjanjian mudharabah tersebut pihak pengelola dana dilepaskan dari sistem jaminan atau ada pihak yang ketiga yang menjamin, hal ini dilakukan supaya terciptanya keadilan di antara nasabah/mudharib dan pihak bank sehingga dapat melindungi diri dari kerugian.

Adapun permasalahan dalam penelitian ini adalah Bagaimanakah pelaksanaan perjanjian pembiayaan mudharabah pada Bank Syariah, Bagaimanakah pihak Bank menyelesaikan pembiayaan mudharabah yang bermasalah pada Bank Syariah, Sanksi apakah yang diberlakukan kepada mudharib bila melanggar perjanjian dalam akad pembiayaan Mudharabah

Untuk menjawab permasalahan di atas penelitian menggunakan metode yuridis normatif yang bersifat kualitatif dengan cara menganalisis data primer dan sekunder dan tersier serta bahan wawancara sehingga menghasilkan jawaban dari setiap permaslaahan yang di kemukakan.

Berdasarkan penelitian dapat di simpulkan antara lain pengaturan perjanjian pembiayaan mudharabah berdasarkan kitab suci Al-Qur'an, Al-Hadist, Dewan Fatwa Syari'ah Nasional MUI, Undang-Undang No.21 Tahun 2008 tentang Perbankan Syari'ah dan Undang-Undang No. 10 Tahun 1998 Tentang Perbankan.
\end{abstract}

Kata kunci $\quad$ :Perjanjian Pembiayaan ; Prinsip Mudharabah ; Bank Syariah 
THE ANALYSIS ON THE IMPLEMENTATION OF FINANCING AGREEMENT

WITH MUDHARABAH PRINCIPLES IN SHARIA BANKS IN THE STUDY OF

ACT NO. 21 YEAR 2008 CONCERNING SHARIA BANKING

By

Prof. H. Abdullah Kelib, S.H and Sodikul Amin

\begin{abstract}
The Mudharabah Financing Agreement is based on trust, with another understanding that the investor will hand over the funds to the fund manager party after the investor is sure that the borrower of the capital both skillfully and morally is trustworthy to manage the capital provided with his expertise and will not manipulate the capital. However, it does not mean that in the implementation of the mudharabah agreement the fund management party is released from the guarantee system or there is third party who guarantee it. This is done in order to create justice among customers / mudharib and the bank so it can protect themselves from the loss.

The problems in this research are how the implementation of mudharabah financing agreement in Sharia Banks, how the Banks solve the in trouble mudharabah financing in Sharia Banks, what sanction is implemented to mudharib if they break the agreement in Mudharabah financing agreement.

To answer the above problems, this study uses juridical normative method qualitatively by analyzing primary, secondary and tertiary data as well as interview materials therefore produces the answer of each problems given.

Based on the research it can be concluded that, among others, the arrangement of mudharabah financing agreement is based on the holy Al-Qur'an, Al-Hadist, National Sharia Fatwa Council of MUI, Act No. 21 Year 2008 on Sharia Banking and Act No. 10 Year 1998 About Banking.
\end{abstract}

Keywords: Financing Agreement; Mudharabah Principle; Sharia Bank

\section{PENDAHULUAN}

\subsection{Latar Belakang}

Perekonomian yang berbasis pada nilai-nilai dan prinsip Syariah sudah cukup lama dinantikan ummat Islam di Indonesia maupun dari belahan dunia lainnya. Penerapan nilai-nilai dan prinsip Syariah dalam segala aspek kehidupan dan dalam aktivitas transaksi antar ummat didasarkan pada aturan-aturan Syariah sudah cukup lama diperjuangkan dan diharapkan eksis dalam pembangunan ekonomi. Keinginan ini didasari oleh suatu kesadaran untuk menerapkan Islam secara utuh dan total dalam segala aspek kehidupan, sebagaimana dijelaskan dalam Surat Al-Baqarah 
ayat (208) yang terjemahannya

berbunyi sebagai berikut:

Ayat tersebut dengan tegas mengingatkan bahwa selama Islam diterapkan secara parsial, maka ummat Islam akan mengalami keterpurukan duniawi dan kerugian ukhrawi. Hal ini sangat jelas, sebab selama Islam hanya diwujudkan dalam bentuk ritualisme ibadah semata, hanya diingat pada saat kelahiran bayi, ijab qabul pernikahan, serta penguburan mayat, sementara dimarginalkan dari dunia politik,ekonomi perbankan, asuransi, pasar modal, pembiayaan proyek, dan transaksi ekspor impor, maka umat Islam telah mengubur Islam dalamdalam dengan tanganya sendiriSehubungan dengan hal tersebut di atas Muhammad Safi'i Antonio menyatakan bahwa :

"Sangat disayangkan, dewasa ini masih banyak kalangan yang melihat bahwa Islam tidak berurusan dengan bank dan pasar uang, karena yang pertama adalah dunia putih sementara yang kedua adalah dunia hitam, penuh tipu daya dan kelicikan. Oleh karena itu tidak mengherankan bila beberapa cendikiawan dan ekonomi melihat Islam, dengan sistem nilai dan tatanan normatifnya, sebagai factor penghambat pembangunan (an obstacle to economic growth).
Penganut paham liberalisme dan pragmatism sempit ini menilai bahwa kegiatan ekonomi dan keuangan akan semakin meningkat dan berkembang bila dibebaskan dari nilai-nilai normative dan rambu-rambu Ilahi”.

Bank merupakan lembaga keuangan yang mempunyai peranan yang sangat strategis dalam menyelesaikan dan mengembangkan unsur-unsur trilogy pembangunan nasional. Kegiatan utama dari perbankan adalah menyerap dana dari masyarakat. Hal ini terutama karena fungsi bank sebagai perantara (intermediary) pihak-pihak kelebihan dana (surplus of funds) dan pihak yang memerlukan dana (luck of funds). Sebagai agent of development, bank merupakan alat pemerintah dalam membangun perekonomian bangsa melalui pembiayaan semua jenis usaha pembangunan, yaitu sebagai financial intermediary (perantara keuangan) yang memberikan kontibusi terhadap pendapatan Negara.

Keberadaan lembaga perbankan selain berpengaruh terhadap dunia usaha, dimana hampir semua dunia usaha mengandalkan jasa financial perbankan, juga telah banyak menyerap jutaan orang tenaga kerja. Fungsi utama bank merupakan fungsi 
(tumpuan) yang sangat penting bagi masyarakat dan dunia usaha adalah sebagai tempat penyimpanan dana, dan memberikan kredit kepada masyarakat.

Di Indonesia fungsi bank diartikan sebagai agent of development yaitu sebagai lembaga yang mendukung pelaksanaan pembangunan nasional dalam rangka pemerataan pembangunan dan hasil-hasilnya, pertumbuhan ekonomi dan stabilitas nasional kearah peningkatan taraf hidup rakyat banyak. Untuk meningkatkan peran dan fungsi bank terdapat beberapa kebijakan moniter yang dilaksanakan sejak pemerintahan Orde Baru adalah sebagai berikut :

1. Meningkatkan mobilitas tabungan msyarakat melalui lalu lintas keuangan.

2. Membeikan kredit dalam jumlah yang cukup besar, bank sektorsektor yang mendapat prioritas, maupun sektor-sektor non prioritas untuk meningkatkan kesempatan kerja.

3. Menunjang usaha pemeliharaan dan peningkatan stabilitas ekonomi dan.

4. Menunjang usaha untuk meningkatkan kedudukan golongan ekonomi lemah melalui pemberian kredit KIK (Kredit Investasi Kecil).
Krisis ekonomi yang melanda Indonesia pada pertengahan tahun 1997 menjadi suatu sarana yang sangat strategis dan menggembirakan bagi para entreprentur terutama pengusaha muslim dalam meneruskan produksi usahanya. Hal ini disebabkan kemampuan dari lembaga perbankan syariah yang berorientasi kepada sistem bagi hasil dapat memberikan keuntungan ke setiap pengelola uang, tidak hanya kepada bank sebagai kreditur yang telah memberikan pinjaman tetapi juga kepada nasabah/mudharib sebagai peminjam modal dalam mengembangkan usaha mereka.

Dari sudut pandang kepentingan ekonomi, pembiayaan perbankan syariah yang menggunakan sistem mudharabah (profit sharing) dalam memperlancar roda perekonomian ummat dianggap mampu menekan terjadinya inflansi karena tidak adanya ketetapan bunga yang harus dibayarkan ke bank, juga dapat merubah halauan kaum muslimin dalam setiap transaksi perdagangan dan keuangan yang sejalan dengan ajaran Islam. Dari kenyataan ini pelaksanaan sistem perekonomian Islam dan praktek perbankan non bunga menjadi alternative yang baik, 
di samping merupakan suatu keharusan dan kewajiban dalam menjalankan anjuran agama, apalagi dengan disahkannya Undang-Undang No. 21 Tahun 2008 Tentang Perbankan Syariah dan Undang Undang No. 10 Tahun 1998 sebagai Perubahan Atas Undang-Undang No. 7 Tahun 1992 Tentang Perbankan. Undang-Undang tersebut telah mengatur semua perbankan berdasarkan prinsip syariah.

Prinsip syariah adalah prinsip hukum Islam dalam kegiatan perbankan berdasarkan fatwa yang dikeluarkan oleh lembaga yang memiliki kewenangan dalam penetapan fatwa di bidang syariah. Sedangkan pembiayaan merupakan penyediaan dana atau tagihan yang dipersamakan dengan itu berupa transaksi bagi hasil dalam bentuk mudharabah dan musyarakah, transaksi sewa menyewa dalam bentuk ijarah atau sewa beli dalam bentuk ijarah muntahiya bittamlik, transaksi jual beli dalam bentuk piutang murabahah, salam, dan istisna', transaksi pinjam-meminjam dalam bentuk piutang qardh dan transaksi sewa menyewa jasa dalam bentuk ijarah untuk transaksi multijasa berdasarkan persutujuan atau kesepakatan antara bank syariah dan /atau unit usaha syariah dan pihak lain yang mewajibkan pihak dibiayai dan /atau diberi fasilitas dana untuk mengembalikan dana tersebut setelah jangka waktu tertentu dengan imbalan ujrah, tanpa imbalan, atau bagi hasil.

Pembiayaan mudharabah secara tidak langsung adalah bentuk penolakan terhadap sistem bunga yang diterapkan oleh bank kenvensional dalam mencari keuntungan. Karena itu pelarangan bunga ditinjau dari ajaran Islam merupakan perbuatan riba yang diharamkan dalam Al-qur'an, sebab larangan riba tersebut bukanlah meringankan beban orang yang dibantu dalam hal ini nasabah/mudharib tetapi merupakan tindakan yang memperalat dan memakan harta orang lain tanpa melalui jerih payah dan berisiko serta kemudahan yang diperoleh orang kaya di atas kesedihan Orang miskin.

Dengan demikian perbankan syariah yang memberikan pembiayaan mudharabah terhadap nasabah/mudharib dengan sendirinya akan menjadikan hubungan di antara kedua belah pihak bagaikan mitra dalam meraih keuntungan riil pada pengelolaan usaha mereka.Pada konsep pembiayaan bagi hasil mudharabah dalam perbankan syariah dikenal dengan istilah qiradh akad 
kerja sama antara dua pihak dimana pemilik dana (shahibul maal) menyediakan seluruh modal sedangakan pihak kedua (mudharib) bertindak selaku pengelola dan keuntungan usaha dibagi antara mereka seuai dengan kesepakatan yang dituangkan dalam kontrak.

Hubungan keterikatan antara dua pihak tersebut akan melahirkan konsekuensi yang harus dipenuhi oleh masing-masing pihak yaitu seluruh kewajiban yang harus ditunaikan dan apa-apa yang menjadi hak masingmasing yang akan diterima. Dalam hal ini Al-Qur'an sebagai pedoman dari ajaran Islam yang ditafsirkan dengan realisasi muamalah fiqh menerapkan perjanjian merupakan pernyataan dari seorang untuk mengerjakan atau tidak mengerjakan sesuatu yang berkaitan dengan orang lain.

Dijelaskna dalam Al-Qur'an surah AlBaqarah ayat 282 yang diartikan sebagai berikut:

Hai orang-orang yang beriman, apabia bermuamalah tidak secara tunai untuk waktu yang ditentukan, hendaklah kamu menuliskannya, dan hendaklah seorang penulis di antara kamu menuliskannya dengan benar, dan janganlah penulis enggan menuliskannya sebagaimana Allah telah mengajarkannya, maka hendaklah ia menulis, dan hendaklah orang yang berutan itu mengimlakkan (apa yang akan ditulis itu), dan hendaklah ia bertakwa kepada Allah Tuhannya, dan janganlah ia mengurangi sedikitpun dari utangnya. Jika yang berutang itu orang yang lemah akalnya atau lemah keadaannya atau dia sendiri tidak mampu mengimlakannya maka hendaklah walinya mengimlakkan dengan jujur dan persaksikanlah dengan dua orang saksi dari orang-orang laki-laki (di antaramu). Juga taka da dua orang laki-laki, maka boleh seorang laki-laki dan dua orang perempuan dari saksisaksi yang kamu ridhai, supaya jika seorang lupa maka seorang lagi mengingatkannya. Janganlah saksisaksi itu enggan (memberikan keterangan) apabila mereka Dipanggil, dan janganlah kamu jemu menulis utang itu, baik kecil maupun besar sampai batas waktu pembayarannya. Yang demikian itu lebih adil di sisi Allah dan lebih dapat menguatkan persaksian dan lebih dekat kepada tidak (menimbulkan) keraguan (tulislah muamalah itu) kecuali muamalahmu itu perdagangan dosa yang kamu jalankan di antara kamu maka tidak ada dosa bagi kamu jika kamu tidak menuliskannya. Dan persaksikanlah jika kamu berjual beli 
dan janganlah penulis dan saksi saling sulit menyulitka, jika kamu lakukan (yang demikian) maka sesungguhnya hal itu adalah suatu kefasikan pada dirimu, dan bertakwalah kepada Allah, Allah mengajarimu dan Allah mengetahui segala sesuatu.

Sebagaimana yang telah disebutkan di atas bahwa perjanjian pembiayaan mudharabah merupakan perjanjian kerjasama antara pemilik modal dengan pengelola usaha tanpa memakai agunan, yang mana di dalam akad tersebut dinyatakan akan membagi keuntungan di antara mereka. Maka dapat dipahami bahwa perjanjian mudharabah didasarkan kepada kepercayaan trust investment), dengan pengertian lain bahwa pemodal akan menyerahkan dananya kepada pihak pengelola dana setelah pemodal merasa yakin bahwa peminjam modal tersebut baik secara skill maupun moral dapat dipecaya untuk mengelola modal yang diberika dengan keahliannya dan tidak akan memanipulasi modal tersebut. Namun bukan berarti dalam pelaksanaan perjanjian mudharabah tersebut pihak pengelola dilepaskan dari sistem jaminan atau ada pihak yang ketiga yang menjamin, hal ini dilakukan supaya terciptannya keadilan di antara nasabah/mudharib dan pihak bank sehingga dapat melindungi diri dari kerugian (the end of justice is to secure from injury).

Pembiayaan mudharabah di Bank Syariah tidak terlepas dari mekanisme pelaksanaan perjanjian yang telah ditetapkan berdasarkan syarat dan rukun dalam akad sesuai dengan yangdikemukakan oleh ulama fiqhiyah dan juga Dewan Syariah Nasional MUI tentang mudharabah (qiradh). Oelh karena itu keabsahan suatu perjanjian pembiayaan mudharabah tidak lepas dari pada pemenuhan syarat dan rukun mudharabah itu sendiri.

Adapun rukun dan syarat pembiayaan mudharabah adalah sebagai berikut :

1. Penyedia dana (shahibul maal)

2. Pengelola dana (mudharib) yang cakap hukum.

3. Penyataan ijal dan qabul harus dinyatakan oleh para pihak untu menunjukkan kehendak mereka pada waktu menandatangani akad (kontrak).

4. Modal, yaitu sejumlah uang dan /atau asset yang diberikan oleh penyedia modal kepada mudharib.

5. Keuntungan, artinya sejumlah kelebihan yang dapat sebagai kelebihan dari modal.

6. Kegiatan usaha oleh pengelola (Mudharib) sebagai pemibangan 
modal yang disediakan oelh penyedia dana.

Adanya klausula yang menentukan sahnya suatu perjanjian di dalam Keputusan Dewan Syariah yang berlandaskan hukum Islam dan telah dipakai bank syariah sebagai rujukan dalam pembiayaan mudharabah merupakan suatu gambaran bahwa di dalam perbankan syariah seorang mudharib harus memenuhi segala klausula yang tertuang dalam isi kontrak, suatu perjanjian berupa kewajiban yang harus ditunaikan setelah pengelolaan usaha. Dengan demikian pelaksanaan suatu perjanjian pembiayaan dengan prinsip bagi hasil (mudharabah) antara mudhraib dan shahibul maal tersebut seyogianya memberikan gambaran keuntungan kepada kedua belah pihak.

Sebelum disahkannya UndangUndang No. 21 Tahun 2008 Tentang Perbankan Syariah, dalam menjalankan perannya, Bank Syariah berlandaskan pada UU No. 7 tahun 1992 tentang Perbankan dan Peraturan Pemerintah Nomor 72 tahun 1992 tentang Bank berdasarkan prinsip bagi hasil yang kemudian dijabarkan dalam Surat Edaran Bank Indonesia No. 25/4/BPPP tanggal 29 Februari 1993, yang pada pokoknya menetapkan halhal antara lain:
1) Bahwa Bank berdasarkan bagi hasil adalah Bank umum dan Bank perkreditan rakyat yang melakukan usaha semata-mata berdasarkan Prinsip bagi hasil.

2) Prinsip bagi hasil yang dimaksud adalah prinsip bagi hasil yang berdasarkan syariah;

3) Bank berdasarkan bagi hasil wajib memiliki Dewan Pengawas Syariah;

4) Bank umum atau Bank perkreditan rakyat yang kegiatan usahanya semata-mata berdasarkan prinsip bagi hasil tidak diperkenankan melakukan usaha yang tidak berdasarkan prinsip bagi hasil. Sebaliknya Bank umum atau Bank perkreditan rakyat yang kegiatan usahanya tidak berdasarkan kepada prinsip bagi hasil tidak diperkenankan melakukan kegiatan usaha berdasarkan prinsip bagi hasil. Pada tahun 1998 muncul UU No. 10 Tahun 1998 tentang Perubahan Atas UU No. 7 tahun 1992 tentang Perbankan. Dalam Undang-Undang ini terdapat beberapa perubahan yang memberikan peluang lebih besar bagi pengembangan perbankan syariah.

Bank Syariah lahir sebagai salah satu alternative terhadap persoalan bunga Bank, karena Bank Syariah merupakan lembaga keuangan perbankan yang beroperasi dan 
produknya dengan prinsip dasar tanpa menggunakan sistem bunga dengan menawarkan sistem lain yang sesuai dengan syariah Islam.

Prinsip inilah yang membedakan secara prinsipil antara sistem operasional Bank Syariah dan Bank Konvensional. Bagi Bank konvensional bunga merupakan hal penting untuk menarik invektor menginvestasikan modalnya pada suatu Bank. Semakin tinggi bunganya semakin tertarik para investor menabung. Tingkat suku bangsa merupakan unsur esensial dalam Sistem perbankan konvensional. Bank syariah yang bekerja menggunakan sistem non bunga melalui transaksi dengan menggunakan sistem profit and loss sharing yaitu bagi hasil keuntungan dan kerugian yang terjadi ditanggung oleh kedua belah pihak yaitu mudharib dan shahihul maal.

Dalam sistem bunga Bank dan bagi hasil memiliki sisi persamaan yaitu sama-sama memberikan keuntungan bagi pemilik modal, namun keduanya memiliki perbedaan yang principal, yaitu sistem bunga uang merupakan sistem yang dilarang agama Islam, sedangkan bagi hasil merupakan keuntungan yang tidak mengandung riba sehingga tidak diharamkan oleh ajaran Islam.
Sistem bagi hasil mempunyai keuntungan sebab tidak akan menimbulkan negative spread, pertumbuhannya modal negative, dalam permodalan Bank sebagaimana yang biasa terjadi dalam perbankan konvensional yang menggunakan sistem bunga. Hal itu terjadi, di satu pihak disebabkan karena adanya tingkat suku bangsa deposito yang tinggi, dan dilain pihak bunga kredit dibebani tingkat bunga yang rendah untuk menarik para investor menanamkan modalnya.

Penentuan bunga dibuat waktu akad berlangsung dengan asumsi harus selalu untung, tidak ada asumsi kerugian. Pembayaran bunga tetap dilakukan misalnya dalam suatu proyek, tanpa mempertimbangkan apakah proyek yang dijalani itu mempunyai keuntungan atau tidak. Sedangkan sistem bagi hasil penentuan besarnya rasio atau nisbah bagi hasil di buat pada waktu akad dengan perpedoman pada kemungkinan untuk dan rugi. Maka dalam suatu proyek yang dilakukan nasabah, apabila mengalami kerugian akan ditanggung bersama. Sisi lain pada sistem bagi hasil, jumlah pembagian laba menu=ingkat sesuai dengan peningkatan jumlah pendapatan sedangkan konvensional 
jumlah pembayaran bunga tidak meningkat meskipun jumlah keuntungan berlipat.

Bank Islam dengan sistem bagi hasil sebagai alternative pengganti dari penerapan sistem bunga ternyata dinilai telah berhasil menghindari dampak negative dari penerapan bunga, seperti :

1. Pembebanan pada nasabah berlebih-lebihan dengan beban bunga berbunga (compound interrst) bagi nasabah yang tidak mampu membayar pada waktu temponya ;

2. Timbulnya pemerasan (eksploitasi)yang kuat terhadap yang lemah ;

3. Terjadinya konsentrasi kekuatan ekonomi di tangan kelompok elit, para bankir dan pemilik modal ;

4. Kurangnya peluang bagi kekuatan ekonomi lemah untuk mengembangkan potensi usaha. Selain mampu dapat menghindarkan dampak negative peranan bunga, Bank dengan sistem bagi hasil dinilai mengalokasikan sumber daya dan sumber dana secara efisien. Kemampuan untuk mengalokasikan sumber daya dan sumber dana secara efisien merupakan modal utama untuk menghadapi persaingan pasar dan perolehan laba.
Di dalam Peraturan Pemerintah dijelaskan lebih lanjut bahwa "yang dimaksud dengan prinsip bagi hasil dalam peraturan ini adalah prinsip muamalat berdasarkan syariat dalam melakukan kegiatan usaha Bank".

Manajemen Bank konvensional dan Bank Syariah pada umunya memiliki persamaan terutama dalam sisi teknis penerimaan uang, mekanisme transfer, tehnologi computer yang digunakan, syarat-syarat umum memperoleh pembiayaan, proposal, laporan keuangan dan sebagainya. Namun dengan adanya landasan syariah serta sesuai dengan Peraturan Pemerintah menyangkut Bank Syariah antara lain UU No. 7 tahun 1992 tentang perbankan sebagaimana telah diubah dengan UU No. `10 tahun 1998 juga terdapat beberapa hal perbedaan diantaranya yang menyangkut aspek legal, struktur organisasi, usaha yang dibiayai, dan lingkungan kerja serta adanya Dewan Pengawas Syariah dalam struktur oraganisasi serta adanya sistem bagi hasil.

Secara umum pembiayaan yang diberikan atau dikeluarkan oleh Bank Syariah meliputi tiga (3) kerangka ('aqd) pembiayaan besar

1. Pembiayaan ber-'aqd tijarah (Jualbeli)Pembiayaan ini digolongkan sebagai pembiayaan yang bersifat 
investasi, jenis produk pembiayaan yang dikeluarkan meliputi :

a. Al-Ba'I Bitsaman Ajil (Jual beli dengan cara angsuran);

b. Al-Murabahah (Jual beli dengan cara jatuh tempo);

c. Produk Ijarah (sewa menyewa);

2. Pembiayaan ber-'aqd syarikah (kerja sama / kongsi)

Digolongkan sebagai pembiayaan yang bersifat modal kerja, jenis produk pembiayaan syarikah meliputi

a. Pembiayaan Al-Musyarakah (pembagian dengan jumlah modal sebagian sebagian antara pihak Bank dengan pihak peminjam);

b. Pembiayaan Al-Mudharabah (pembiayaan dengan dana 100\% dari pihak Bank).

3. Pembiayaan ber-'aqd hasan (kebijakan)

Berdasarkan uraian tersebut diatas, maka peneliti tertarik untuk mengangkat judul "Analisis Terhadap Pelaksanaan Perjanjian Pembiayaan Dengan Prinsip Mudharabah Pada Bank Syariah Dalam Kajian UU NO.

21 Tahun 2008 Tentang Perbankan Syariah".

B. Rumusan Masalah

Dari latar belakang tersebut maka terdapat berapa masalah yang menjadi tema pembahasan tesis ini yaitu sebagai berikut :

1. Bagaimana pelaksanaan perjanjian pembiayaan mudhorobah pada perbankan syariah?

2. Bagaimana kendala dan solusi atas permasalahan pelaksanaan perjanjian pembiayaan dengan prinsip mudhorobah pada bank syariah dalam kajian UU NO. 21 Tahun 2008 Tentang Perbankan Syariah?

C. Tujuan Penelitian

Bertitik tolak dari permasalahan yang telah dilakukan di atas, maka tujuan yang hendak dicapai dalam penelitian ini adalah :

1. Untuk memahami pelaksanaan perjanjian pembiayaan mudhorobah pada Bank Syariah BRI Cabang Semarang.

2. Untuk memahami Kesesuaian Prinsip Perjanjian-perjanjian di PT. Bank Syariah BRI Cabang Semarang sesuai dengan prinsip Mudhorobah.

D. Manfaat Penelitian

Dari hasil penelitian ini diharapkan dapat memberikan manfaat sebagai berikut :

\section{Secara Teoritis}

a. Dari segi teoritis kegiatan penelitian ini diharapkan dapat memberikan manfaat berupa sumbangan saran dalam ilmu pengetahuan berupa teori/gagasan perkembangan ilmu 
hukum, khususnya hal-hal yang berkaitan dengan masalah perjanjian pembiayaan dengan prinsip bagi hasil tersebut.

b. Di samping itu dari aspek teoritis, penelitian ini juga akan memberikan informasi mengenai alternatif konsep yang lebih baik dalam perjanjian pembiayaan dengan prinsip bagi hasil tersebut

c. Dapat mendukung penelitian yang aka datang

\section{Secara Praktis}

a. Diharapkan dapat memberikan masukan kepada pemerintah khususnya para pengelola bank untuk lebih mengefektifkan pelaksanaan perjanjian pembiayaan dengan prinsip bagi hasil tersebut

b. Hasil penelitian ini diharapkan dapat mengungkap berbagai permasalahan dan kendala yang timbul dalam pelaksanaan perjanjian pembiayaan dengan prinsip bagi hasil tersebut

c. Diharapkan dapat memberikan alternatif bagi penelitian selanjutnya dalam merumuskan pelaksanaan perjanjian pembiayaan dengan prinsip bagi hasil tersebut.

\section{.4. Teknik Pengumpulan Data}

Mengingat penelitian ini adalah penelitian yang bersifat yuridis normatif yang memusatkan perhatian pada data primer, pengumpulan data dilakukan dengan cara studi dokumen, yaitu dengan menghimpun data yang berasal dari kepustakaan yang berupa peraturan Perundang-undangan, bukubuku, internet dan data- data yang diperoleh dilapangan yang mempunyai hubungan dengan permasalahan yang diteliti dalam tesis ini.

\section{Analisis Data}

"Analisis data adalah proses mengorganisasikan dan mengurut data kedalam pola, kategori, dan satuan uraian dasar, sehingga dapat ditemukan tema dan dapat dirumuskan hipotesis kerja seperti yang disarankan oleh data". Setelah data primer diperoleh, selanjutnya data tersebut diidentifikasi dan diklasifikasikan serta disusun dalam bentuk tabel frekuensi, dianalisis secara kualitatif dengan mempelajari seluruh jawaban dari responden, membandingkan dengan data sekunder, dengan menggunakan metode berfikir secara induktif dan deduktif.

Pada proses induktif, proses berasal dari proposisi (sebagai hasil pengamatan dan berakhir pada kesimpulan pengetahuan baru) berupa asas umum. Sedangkan pada prosedur deduktif, bertolak dari satu proposisi umum yang kebenarannya telah diketahui dan berakhir pada satu kesimpulan (pengetahuan baru) yang 
bersifat lebih khusus, sehingga nanti diharapkan mampu menjawab masalah yang berkaitan dengan perjanjian pembiayaan dengan prinsip bagi hasil tersebut

\section{LANDASAN TEORI}

\section{A. Pengertian Perjanjian}

Pengertian perjanjian diatur dalam Pasal 1313 KUH Perdata yang menyebutkan bahwa "suatu persetujuan adalah perbuatan dengan mana satu orang atau lebih mengikat dirinya terhadap satu orang atau lebih“. Pasal ini tidak memberikan batas yang jelas. Hal ini dikarenakan disatu sisi terlalu luas dan disisi lain kurang lengkap.

- Kata "perbuatan” terlalu luas pengertiannya karena dengan kata itu seakan-akan semua perbuatan termasuk juga didalamnya perbuatan melawan hukum. Padahal perbuatan yang dimaksud dalam definisi tersebut adalah perbuatan hukum.

- Kalimat "satu orang atau lebih mengikat dirinya terhadap satu orang atau lebih", dikatakan kurang lengkap karena dengan kalimat tersebut perjanjian yang termasuk didalamnyahanyalah perjanjian sepihak sehingga perjanjian yang sifatnyatimbal balik tidak termasuk didalamnya. Oleh karena itu supaya perjanjian yang bersifat timbal balik termasuk didalamnya maka perlu ditambah kata "saling" dalam definisi Pasal 1313 KUH Perdata.

Pengertian yang lebih lengkap dikemukakan oleh R. Subekti, yang memberikan definisi perjanjian adalah "suatu peristiwa di mana seseorang berjanji kepada orang lain atau dimana Berdasarkan beberapa pengertian diatas dapat disimpulkan bahwa perjanjian ialah suatu hubungan hukum antara dua orang atau lebih berdasarkan kata sepakat untuk menimbulkan suatu akibat hukum sesuai peraturan atau kaidah yang mengikat mereka untuk ditaati dan dijalankan. Kesepakatan antara para pihak tersebut akan menimbulkan suatu hak dan kewajiban yang jika dilanggar akan ada akibat hukumnya atau dapat dikenai sanksi.

1. Asas-Asas Perjanjian

Menurut Sudikno, yang dimaksud dengan asas hukum adalah : "Suatu pikiran dasar yang bersifat umum yang melatarbelakangi pembentukan hukum positif. Dengan demikian asas hukum tersebut pada umumnya tidak tertuang di dalam peraturan yang kongkrit akan tetapi hanya merupakan suatu hal yang menjiwai atau melatarbelakangi pembentukannya. 
Hal ini disebabkan sifat dari asas tersebut adalah abstrak dan kongkrit.

Adapun asas-asas yang terdapat dalam hukum perjanjian adalah sebagai berikut :

\section{a. Asas Kebebasan Berkontrak}

Asas kebebasan berkontrak adalah suatu asas yang menentukan bahwa setiap orang adalah bebas atau leluasa untuk memperjanjikan apa dan kepada siapa saja.

Asas ini terdapat dalam Pasal 1338 ayat (1) KUH Perdata yang menyatakan bahwa "semua perjanjian yang dibuat secara sah berlaku sebagai undang-undang bagi merekayang membuatnya". Asas ini dapat disimpulkan dari kata "semua" yang mengandung makna yaitu :

1) Setiap orang bebas untuk mengadakan atau tidak mengadakan perjanjian;

2) Setiap orang bebas untuk mengadakan perjanjian dengan siapapun yang dikehendakinya;

3) Setiap orang bebas untuk menentukan bentuk perjanjian yang dibuatnya;

4) Setiap orang bebas untuk menentukan isi dan syarat-syarat perjanjian yang dibuatnya;

5) Setiap orang bebas untuk menentukan ketentuan-ketentuan hukum yang berlaku bagi

perjanjian yang dibuatnya.

Meskipun Pasal 1338 ayat (1) menentukan adanya kebebasan setiap orang untuk mengadakan perjanjian namun kebebasan tersebut tidaklah bersifat mutlak. Maksudnya bebas tidak berarti sebebas-bebasnya tetapi ada pembatasannya yaitu tidak dilarang oleh undang-undang serta tidak bertentangan dengan ketertiban umum dan kesusilaan. Hal ini disebutkan dalam Pasal 1339 ayat (1) KUH Perdata yang menyatakan bahwa "perjanjian-perjanjian tidak hanya mengikat untuk hal-hal yang tegas dinyatakan didalamnya, tetapi juga untuk segala sesuatu yang menurut sifatnya perjanjian diharuskan oleh kepatutan, kebiasaan dan undangundang."

b. Asas Konsensualisme.

Asas ini mengandung arti bahwa perjanjian itu terjadi sejak saat tercapainya kata sepakat antara pihakpihak mengenai pokok perjanjian. Sejak saat itu perjanjian mengikat dan mempunyai akibat hukum.

Asas konsensualisme diatur dalam Pasal 1338 ayat (1) jo Pasal 1320 KUH Perdata yang menyatakan bahwa "semua perjanjian yang dibuat secara sah berlaku sebagai undang-undang bagi mereka yang membuatnya". 
"Kata ....yang dibuat secara sah...." pada pasal tersebut harus dihubungakan dengan ketentuan Pasal 1320 KUH Perdata yang mengatur tentang syarat sahnya perjanjian. Sepakat adalah syarat sah perjanjian. Dengan demikian dapat disimpulkan bahwa perjanjian itu lahir apabila sudah tercapai kesepakatan mengenai hal-hal pokok yang menjadi obyek perjanjian dan tidak perlu adanya formalitas tertentu selain yang telah ditentukan undang-undang.

c. Kekuatan Mengikatnya Perjanjian Asas Pacta Sun Servanda.

Asas ini berhubungan dengan akibat suatu perjanjian dan diatur dalam Pasal 1338 ayat (1) dan (2) KUH Perdata. Asas tersebut dapat disimpulkan dari kata “... berlaku sebagai undang-undang bagi mereka yang membuatnya." Dengan adanya asas ini berarti para pihak harus mentaati perjanjian yang telah mereka buat seperti halnya mentaati undangundang, maksudnya yaitu apabila di antara para pihak tersebut melanggar perjanjian yang dibuat, maka akan ada sanksi hukumnya sebagaimana ia melanggar undang-undang. Oleh karena itu akibat dari asas ini adalah perjanjian itu tidak dapat ditarik kembali tanpa persetujuan pihak lain. Hal ini disebutkan dalam Pasal 1338 ayat (2) KUH Perdata yaitu "Suatu perjanjian tidak dapat ditarik kembali selain dengan sepakat kedua belah pihak, atau karena alasan-alasan yang oleh undang-undang dinyatakan cukup untuk itu."

Asas pacta sun servanda disebut juga sebagai asas kepastian hukum. Dengan adanya kepastian hukum maka para pihak yang telah menjanjikan sesuatu akan memperoleh jaminan yaitu apa yang telah diperjanjikan itu akan dijamin pelaksanaannya. Oleh karena itu dalam asas ini dapat disimpulkan adanya kewajiban bagi pihak ketiga (hakim) untuk menghormati perjanjian yang telah dibuat oleh para pihak, artinya hakim tidak boleh mencampuri isi perjanjian tersebut yaitu bahwa pihak ketiga tersebut tidak diperkenankan untuk mengubah, menambah, mengurangi atau bahkan menghapus ketentuan-ketentuan yang merupakan isi dari perjanjian yang telah disepakati oleh para pihak yang membuatnya.

d. Asas Itikad Baik Suatu perjanjian harus dibuat dengan itikad baik oleh para pihak yang membuatnya. Asas itikad baik ini dapat dibedakan antara itikad baik yang subyektif dan itikad baik yang obyektif, Itikad baik yang subyektif dapat diartikan sebagai kejujuran seseorang dalam melakukan 
suatu perbuatan hukum yaitu apa yang terletak pada sikap batin seseorang pada waktu diadakan perbuatan hukum.

Sedangkan itikad baik dalam pengertian yang obyektif, maksudnya bahwa pelaksanaan suatu perjanjian itu harus didasarkan pada norma kepatutan atau apa-apa yang dirasakan sesuai yang patut dalam masyarakat.

2. Syarat Sahnya Perjanjian

Suatu perjanjian dinyatakan sah dan mempunyai akibat hukum apabila perjanjian tersebut memenuhi syarat sahnya perjanjian yang ditetapkan dalam Pasal 1320 KUH Perdata, yaitu

a. Sepakat bagi mereka yang mengikat dirinya;

b. Kecakapan untuk membuat suatu perjanjian

c. Suatu hal tertentu;

d. Suatu sebab yang halal.

Dari keempat syarat sahnya perjanjian tersebut, syarat pertama dan kedua disebut syarat subyektif karena menyangkut orang-orang atau subyek yang mengadakan perjanjian. Syarat subyektif ini apabila tidak dipenuhi maka perjanjian tersebutdapat dimintakan pembatalannya (vernietgbaar) oleh pihak yang lemah yaitu pihak yang tidak cakap atau pihak yang memberikan sepakat secara tidak bebas.

Selanjutnya untuk syarat sahnya perjanjian yaitu bahwa suatu perjanjian harus mengenai suatu hal tertentu yang merupakan pokok perjanjian yaitu obyek perjanjian.

Berdasarkan Pasal 1333 ayat (1) dan (2) KUH Perdata, disebut bahwa suatu perjanjian harus mempunyai sebagai pokok suatu barang yang paling sedikit ditentukan jenisnya, dan tidaklah menjadi halangan bahwa jumlah barang tidak ditentu, asal saja jumlah itu kemudian dapat ditentukan atau dihitung. Selanjutnya didalam Pasal 1334 KUH Perdata dinyatakan pula bahwa barang-barang yang baru akan ada dikemudian hari dapat menjadi pokok suatu perjanjian ialahbarang-barang/ benda yang sudah ada maupun barang/ benda yang masih akan ada..

\section{d. Suatu Sebab Yang Halal}

Suatu sebab atau causa yang halal yang dimaksud Pasal 1320 KUH Perdata bukanlah sebab dalam arti yang menyebabkan atau yang mendorong orang membuat perjanjian melainkan sebab dalam arti "isi perjanjian itu sendiri" yang menggambarkan tujuan yang akan dicapai oleh pihak-pihak, apakah 
bertentangan dengan ketertiban umum dan kesusilaan atau tidak.

Akibat hukum perjanjian yang berisi causa yang tidak halal ialah "batal". Dengan demikian tidak ada dasar untuk menuntut pemenuhan perjanjian dimuka hakim, karena sejak semula dianggap tidak pernah ada perjanjian. Demikian juga apabila perjanjian yang dibuat itu tanpa causa, maka dianggap tidak pernah ada (Pasal 1335 KUH Perdata).

\section{Perjanjian Dalam Hukum Islam}

Islam merupakan agama yang bersifat rahmatan lil alamin artinya agama yang menjadi rahmat bagi seluruh alam. Ajaran Islam telah membuat pengaturan yang komperehensif dan universal sehingga kehidupan manusia senantiasa saling menjaga hubungan baik antara satu individu dengan individu lainnya dan juga menjaga hubungan yang bersifat transendental spiritual dengan Sang Khaliq yakni Allah SWT.

Hubungan vertikal kepada Allah SWT bisa terwujud dengan melaksanakan perintah-Nya dan menjauhi segala larangan-larangan-Nya, di sisi lain manusia senantiasa berhubungan dengan manusia lainnya dalam bentuk muamalah baik di bidang harta kekayaan maupun hubungan kekeluargaan, hubungan sesama manusia khususnya di bidang harta kekayaan biasanya dapat diwujudkan dalam bentuk perjanjian atau akad.

Dalam Al-Qur'an ada terdapat dua (2) istilah yang menyangkut dengan perjanjian, yaitu kalimat al-aqdu (akad) dan al-'ahdu (janji). Al-Qur'an mamakai kalimat pertama dalam arti perikatan atau perjanjian, sedangkan kalimat yang kedua dalam Al-Qur'an berarti masa, pesan, penyempurnaan dan janji atau perjanjian.

Dalam Pasal 1 ayat (13) UndangUndang Nomor 21 Tahun 2008 Tentang Perbankan Syariah disebutkan bahwa Akad adalah kesepakatan tertulis antara Bank Syariah atau Unit Usaha Syariah dan pihak lain yang memuat adanya hal dan kewajiban bagi masing-masing pihak sesuai dengan prinsip syariah.

Dalam pandangan ulama syafi'iyah, Hanafiyah dan Hanabilah, akad merupakan segala sesuatu yang dikerjakan oleh seseorang berdasarkan keinginannya sendiri, seperti wakaf, pembebasan, atau sesuatu yang pembentukannya membutuhkan keinginan dua orang seperti jual beli dan gadai.

Dari definisi Akad sebagaimana tersebut di atas, penulis menyimpulkan bahwa perjanjian atau akad adalah perjanjian yang dilakukan 
oleh dua pihak yang bertujuan untuk saling mengikatkan diri satu sama lainnya, dengan diwujudkan dalam ijab dan qabul yang objeknya sesuai dengan syariah, dengan pengertian lain bahwa perjanjian tersebut berlandaskan keridhoan atau kerelaan secara timbal balik dari kedua belah pihak terhadap objek yang diperjanjikan dan tidak bertentangan dengan prinsip syariah. Dengan demikian akad atau perjanjian akan menimbulkan kewajiban prestasi pada satu pihak dan hak bagi pihak lain atas prestasi tersebutDari definisi di atas dapat dipahami bahwa dalam menentukan sah atau tidaknya suatu perjanjian dapat dilihat dari pernyataan perjanjian tersebut memakai ijab dan qabul, dan harus ada pihak-pihak yang melaksanakan perjanjian, di samping bahwa objek yang ada dalam perjanjian tersebut harus dibenarkan oleh syariah. Sementara itu Ulama fiqh juga telah menetapkan syarat akad sebagai berikut:

a. Mukallaf, artinya pihak yang melakukan akad tersebut telah cakap bertindak secara hukum.

b. Akad tersebut diakui oleh syarae

c. Akad itu tidak dilarang oleh nash.

d. Akad yang dilakukan itu memenuhi syarat-syarat khusus yang terkait dengan yang diakadkan.

e. Akad tersebut bermanfaat.

Kemudian rukun akad harus meliputi beberapa unsur yaitu :

a. Para pihak yang membuat akad (al'aqidain),

b. Pernyataan kehendak para pihak (shighatul-'aqd),

c. Objek akad (mahallul-' aqd), dan

d. Tujuan akad (maudhu'-al'aqd).

Di dalam al-Qurean

Maka dalam mewujudkan suatu kesepakatan dalam sebuah kontrak dalam setiap perjanjian sebagaimana dalam rukun akad, mesti ada kehendak dari pada pihak yang ingin mengikatkan diri, artinya kebebasan untuk mengikatkan diri tersebut menjadi sebuah syarat yang membuat suatu perjanjian menjadi sah atau tidak, kemudian karena pada prinsipnya perjanjian pembiayaan mudhārabah tidak ada jaminan artinya bahwa perjanjian ini hanya didasari kepada kepercayaan bank terhadap nasabah/mudharib, maka dengan sendirinya seorang nasabah/mudharib akan melaksanakan kewajibannya sebagaimana halnya dengan Bank Syariah juga harus memperhatikan kepentingan dari nasabah/mudharib dalam situasi tertentu. 
Di dalam Peraturan Pemerintah dijelaskan lebih lanjut bahwa "yang dimaksud dengan prinsip bagi hasil dalam peraturan ini adalah prinsip muamalat berdasarkan syariat dalam melakukan kegiatan usaha Bank". Secara umum pembiayaan yang diberikan atau dikeluarkan oleh Bank Syariah meliputi tiga (3) kerangka (,aqd) pembiayaan besar :

a. Pembiayaan ber-'aqd tijarah (Jualbeli). Pembiayaan ini digolongkan sebagai pembiayaan yang bersifat investasi, jenis produk pembiayaan yang dikeluarkan meliputi:

1) Al-Ba'i Bitsaman Ajil (jual beli dengan cara angsuran);

2) Al-Murabahah (jual beli dengan cara jatuh tempo);

3) Produk Ijarah (sewa menyewa);

b. Pembiayaan ber-'aqd syarikah (kerja sama/kongsi).

Digolongkan sebagai pembiayaan yang bersifat modal kerja, jenis produk pembiayaan syarikah meliputi:

1) Pembiayaan al-Musyarakah (pembiayaan dengan jumlah modal sebagian sebagian antara pihak Bank dengan pihak peminjam);

2) Pembiayaan al-Mudhārabah (pembiayaan dengan dana 100\% dari pihak Bank).

3) Pembiayaan ber-'aqd hasan (kebajikan) Pembiayaan ber-'aqd hasan adalah pembiayaan yang berorentasi pada kebajikan, yaitu Bank yang memberikan pembiayaan kepada pihak -pihak yang tergolong dalam delapan asnaf.

Keberadaan perbankan Islam di tanah air telah mendapat landasan yang kokoh setelah adanya paket deregulasi yaitu, berkaitan dengan berlakunya Undang-Undang No. 21 Tahun 2008 Tentang Perbankan Syariah, Undang Undang No. 7 Tahun 1992 yang direvisi melalui Undang-Undang No. 10 Tahun 1998 Tentang Perbankan yang dengan tegas mengakui keberadaaan dan berfungsinya sistem bagi hasil dalam bank syariah. Dengan demikian pembiayaan mudhārabah dengan prinsip bagi hasil yang diterapkan dalam perbankan syariah merupakan cerminan dari kegiatan muamalah

\section{HASIL PENELITIAN}

\section{A. Pelaksanaan Perjanjian}

Pembiayaan Mudharabah Pada

\section{Bank Syariah}

Pembiayaan mudhārabah secara tidak langsung adalah bentuk penolakan terhadap sistem bunga yang diterapkan oleh bank konvensional dalam mencari keuntungan. Karena itu pelarangan bunga ditinjau dari ajaran Islam merupakan perbuatan riba yang diharamkan dalam Al-Qur'ean, sebab 
larangan riba tersebut bukanlah meringankan beban orang yang dibantu, dalam hal ini nasabah/mudharib tetapi merupakan tindakan yang memperalat dan memakan harta orang lain tanpa melalui jerih payah dan berisiko serta kemudahan yang diperoleh orang kaya di atas merupakan kesedihan orang miskin.

Pada konsep pembiayaan mudhārabah dalam perbankan syariah dikenal dengan istilah Qiradh. Qiradh adalah akad kerja sama antara dua pihak dimana pemilik dana (shahibul maal) menyediakan seluruh modal sedangkan pihak kedua (mudharib) bertindak selaku pengelola dan keuntungan usaha di bagi di antara mereka sesuai dengan kesepakatan yang dituangkan dalam kontrak.

Kontrak tersebut diatur dalam Undang-Undang No. 21 Tahun 2008 Tentang Perbankan Syariah, dalam menjalankan perannya, Bank Syariah berlandaskan pada Undang-Undang No. 7 tahun 19925 tentang Perbankan dan Peraturan Pemerintah Nomor 72 tahun 1992 tentang Bank berdasarkan prinsip bagi hasil yang kemudian dijabarkan dalam Surat Edaran Bank Indonesia No. 25/4/BPPP tanggal 29 Februari 1993, yang pada pokoknya menetapkan halhal antara lain:
1. Bahwa Bank berdasarkan bagi hasil adalah Bank umum dan Bank perkreditan rakyat yang melakukan usaha semata-mata berdasarkan prinsip bagi hasil.

2. Prinsip bagi hasil yang dimaksud adalah prinsip bagi hasil yang berdasarkan syariah;

3. Bank berdasarkan bagi hasil wajib memiliki Dewan Pengawas Syariah;

4. Bank umum atau Bank perkreditan rakyat yang kegiatan usahanya semata mata berdasarkan prinsip bagi hasil tidak diperkenankan melakukan usaha yang tidak berdasarkan prinsip bagi hasil. Sebaliknya Bank umum atau Bank perkreditan rakyat yang kegiatan usahanya tidak berdasarkan kepada prinsip bagi hasil tidak diperkenankan melakukan kegiatan usaha berdasarkan prinsip bagi hasil.

Bank Islam dengan sistem bagi hasil sebagai alternatif pengganti dari penerapan sistem bunga ternyata dinilai telah berhasil menghindarkan dampak negatif dari penerapan bunga, seperti:

1. Pembebanan pada nasabah berlebih-lebihan dengan beban bunga berbunga (compound interest) bagi nasabah yang tidak mampu membayar pada saat jatuh temponya; 
2. Timbulnya pemerasan (eksploitasi) yang kuat terhadap yang lemah ;

3. Terjadinya konsentrasi kekuatan ekonomi di tangan kelompok elit, para bankir dan pemilik modal;

4. Kurangnya peluang bagi kekuatan ekonomi lemah untuk mengembangkan potensi usaha.

Selain mampu menghindarkan dari dampak negatif penerapan bunga, Bank dengan sistem bagi hasil dinilai mengalokasikan sumber daya dan sumber dana secara efisien. Kemampuan untuk mengalokasikan sumber daya dan sumber dana secara efesien merupakan modal utama untuk menghadapi persaingan pasar dan perolehan laba.

Salah satu aspek bagi hasil adalah aspek yang berkaitan dengan bagi risiko. Dalam kerangka kerja kelembagaan saat ini, pemilik modal dapat mendistribusikan risiko melalui pembagian manajemen dan utang dalam bentuk bergabung dalam pemilikan saham. Sementara pemilik tenaga tidak dapat membagikan tenaganya kepada pemilik modal..

Pertama, Al-Musyarakah atau dalam kalimat lain dikenal dengan syirkah menurut ulama Hanafiyah adalah penggabungan harta (dan/atau keterampilan) untuk dijadikan modal usaha dan hasilnya yang berupa keuntungan atau kerugian dibagi bersama. Namun dalam penelitian ini penulis tidak akan membahas tentang pembiayaan musyarakah secara mendalam, sebab pembiayaan yang berhubungan dengan seorang nasabah/mudharib hanya dalam pembiayaan mudhārabah saja.

Kedua, Al-Murabahah yaitu akad jual beli barang dengan menyatakan harga perolehan dan keuntungan (margin) yang disepakati oleh penjual dan pembeli.

Dengan demikian bentuk pembiayaan dalam bank syariah dengan prinsip bagi hasil yang ketiga yaitu Al-mudhārabah adalah sistem pendanaan operasional realitas bisnis, dimana baik sebagai pemilik modal biasanya disebut shahibul maal dengan menyediakan modal $100 \%$ kepada pengusaha sebagai pengelola disebut sebagai mudharib untuk melakukan aktivitas produktif dengan syarat bahwa keuntungan yang dihasilkan akan dibagi di antara mereka sesuai dengan kesepakatan yang disebutkan dalam akad mereka. Jika mengalami kerugian setelah adanya pengelolaan usaha oleh mudharib bukan karena kelalaian yang disengaja maka akan ditanggung oleh investor atau shahibul maal.. 


\section{KESIPULAN PENELITIAN}

A. Kesimpulan

Berdasarkan uraian yang telah dikemukakan di atas, penulis menarik kesimpulan sebagai berikut :

1. Pelaksanaan pembiayaan dengan prinsip bagi hasil yang dilaksanakan harus sesuai dengan ketentuan berlaku, yaitu UU No 21 Tahun 2008 Tentang Perbankan Syariah dan pasal 6 Peraturan Bank Indonesia No: 7/46/2005 tentang akad penghimpunan dan penyaluran dana bagi bank yang melaksanakan kegiatan usaha bedasarkan prinsip syari'ah. Mudharabah merupakan perjanjian atas suatu jenis perkongsian di mana pihak pertama (Shahibul maal) menyediakan dana dan pihak kedua (Nasabah/ Mudharib) bertanggung jawab atas pengelolaan usaha. Dimana landasan perjanjian pembiayaan mudharabah berdasarkan kitab suci Al-Qur'an, Al-Hadist, Dewan Fatwa Syari'ah Nasional MUI, Undang-Undang No.21 Tahun 2008 tentang Perbankan Syari'ah dan Undang-Undang No. 10 Tahun 1998 Tentang Perbankan, Peraturan Bank Indonesia. Dalam Pembiayaan mudharabah muthlaqah Bank Syariah memberikan fasilitas dan otoritas serta hak sepenuhnya kepada mudharib atau nasabah/mudharib untuk melakukan usaha dan mengelola dana yang diperoleh dari pembiayaan mudharabah ini sesuai dengan yang diinginkannya dan hal tersebut akan disebutkan dalam perjanjian atau akad/ kontrak yang disepakati oleh kedua belah pihak. Untuk pembiayaan mudharabah muthlaqah ini pihak Bank Syariah membaginya kepada dua kelompok mudharib, yaitu Mudharib perorangan dan Mudharib badan usaha. Dalam pembiayaan Mudharabah Muqayyadah, dimana Bank sebagai wakil Shahibul Maal menentukan pembatasan atau memberikan syarat kepada nasabah selaku Mudharib dalam mengelola dana seperti untuk melakukan Mudharabah bidang tertentu, cara, waktu dan tempat tertentu saja. Pelaksanaan perjanjian pembiayaan penyaluran dana berdasarkan prinsip bagi hasil pada Bank Syariah dilaksanakan dengan prinsip kehatihatian yang tinggi yang berpedoman pada prinsip $5 \mathrm{C}$ (character, capacity, capital, collateral, conditon of economy) ditambah delapan (8) aspek yaitu : aspek yuridis, manajemen, teknis, pemasaran, keuangan, sosial ekonomi, agunan serta aspek syariah. Pembiayaan Mudharabah dilakukan tanpa perlu adanya penyerahan jaminan oleh nasabah, namun dalam 
prakteknya untuk menghindari terjadinya penyimpangan oleh pengelola usaha/nasabah dan untuk mengurangi resiko, pihak Bank akan meminta jaminan dari nasabah bahwa ia sanggup mengembalikan pembiayan Mudharabah tertentu sesuai dengan yang telah diperjanjikan.

2. Dalam pelaksanaan pembiayaan tersebut ada beberapa kendala. Adapun yang menjadi kendala yaitu: Dalam pengelolaan usaha kadang ada anggota yang belum mampu mengelola usahanya secara baik. Kondisi ekonomi yang tidak stabil pada saat ini. Tingkat kejujuran nasabah yang masih kurang dalam memberitahukan keuntungan bersih dari usaha yang dijalankannya. Masih rendahnya sumber daya manusia nasabah. Faktor musiman terhadap suatu jenis usaha oleh nasabah. Kurangnya pemahaman nasabah dengan prinsip bagi hasil yang menjadi kendala utama. Kurangnya keprofesionalisme bank syariah dalam melaksanakan pembiayaan dalam jumlah besar. Hal yang tak terduga yang menimpa nasabah sehingga nasabah tidak bisa melaksanakan kewajibannya untuk memberikan bagi hasil dari usahanya karena merugi. Penyelesaian atas pembiayaan mudharabah bermasalah dilakukan melalui: 1) Langkah penyelamatan, apabila pembiayaaan masih ada harapan kembali kepada Bank, yaitu resheduling, reconditioning dan restructing. Selain itu dapat pula dilakukan merger, joint venture, atau take over (pengambil- alihan) kegiatan usaha oleh Bank dengan akusisi atau aliansi ; 2) Langkah penyelesaian, perselisihan antara nasabah/ Mudharib dengan Bank Syariah dalam pembiayaan mudharabah lebih mengutamakan penyelesaian dengan cara musyawarah, apabila pembiayaan sulit bahkan sudah tidak ada harapan kembali kepada Bank, upaya yang dapat ditempuh adalah dengan mengajukan gugatan perdata ke lembaga Peradilan Agama atau melalui Badan Arbitrase Syariah Nasional (BASYARNAS), sesuai dengan pilihan penyelesaian sengketa yang disepakati para pihak, sebagaimana yang disebut dalam akad pembiayaan mudharabah.

\section{B. Saran}

1. Bagi pemerintah, hendaknya membuat legal formal ataupun aturan-aturan yang sesuai dengan nilai agama terutama agama Islam dan tidak meninggalkan efek negatif bagi beberapa pihak. Hal tersebut akan menjadi polemik bilamana aturan 
tersebut tidak sesuai bahkan bertentangan dengan nilai agama dan masyarakat.

2. Pihak-pihak yang terkait dalam masalah perbankan khususnya Bank berdasarkan syariah lebih mensosialisasikan keberadaan Bank Syariah kepada masyarakat, terutama terhadap persepsi sebagian masyarakat yang pro dan kontra terhadap halal dan haramnya riba atau bunga Bank serta terhadap keunggulan konsep perbankan syariah yang berdasarkan prinsip kemitraan. Peran pihak Bank Syariah Mandiri dalam memberdayakan pengusaha kecil/golongan ekonomi lemah digiatkan terutama dalam penyediaan pembiayaan/modal serta persyaratan jaminan dipermudah, namun tetap memperhatikan prinsip kehati-hatian, guna menghindarkan risiko kerugian bagi pihak Bank.

3. Terhadap persepsi sebagian masyarakat yang pro dan kontra tentang halal dan haramnya bunga bank (riba), kepada pihak-pihak yang terkait dengan lembaga keuangan syariah agar lebih mensosialisasikan keberadaan perbankan syariah serta meningkatkan pelaksanaan prinsipprinsip perjanjian seperti perjanjian akad mudharabah yang sesuai dengan syariat islam.

\section{DAFTAR PUSTAKA}

Abdullah Saed, Menyoal Bank Sayariah, Kritikan atas Interpretasi Bunga Bank Neo Revivaless, (Jakarta; Paramadina, 2004)

Adiwarman A. Karim, Bank Islam Analisi Fiqh dan Keuangan,(Jakarta: Raja Grafindo Persada, 2004),

Agustianto, Percikan Pemikiran Ekonomi Islam, (Bandung: Cipta pustaka Media, 2002),

Al-Qur'an dan Terjemahannya, (Semarang: Penerbit Assyifa', 1998).

Alvi Syahrin, Pengaturan Hukum dan Kebijakan Pembangunan Perumahan dan Pemukiman Berkelanjutan, (Medan: Pustaka Bangsa Press, 2003),

Ascaya Diana Yunita, Bank Syari'ah: Gambaran Umum (Jakarta: PPSK BI, 2005),

Bismar Nasution, Mengkaji Ulang Sebagai landasan Pembangunan Ekonomi, Pidato pada Pengukuhan Guru Besar, USU- Medan 17 April 2004 ,

Bismar Nasution, Metode Penelitian Hukum Normatif dan Perbandingan Hukum, makalah disampaikan pada Dialog Interaktif Tentang Penenlitian Hukum Pada Majalah Akreditasi, Fakultas Humkum USU, tanggal 18 Februari 2003,

Depertemen Agama, Al-Qur'an dan Terjemahannya, (Semarang; Kamudasmoro Grafindo, 1994),

Gemala Dewi, dkk, Hukum Perikatan Islam Di Indonesia, (Jakarta: Kencana, 